\title{
An Assessment on Induction Heat by Alternate Power
}

\section{G. Hemavathi, S. Sherine, Aarthisuriya}

\begin{abstract}
Incitement heat uses power for the era of warmth, though sun powered vitality is vitality that is basically accessible for era of warmth. Consolidating $s$ vitality that is solar impelling warmth era system will be the productive answer for the warmth generation application that is $g . T$ he proposed framework blessings a control that works contained in two association show reverberation impelling warming with the utilization of vitality that is sun oriented.. The test aftereffect of ordinary warming that is sun oriented prompting that is sun powered are differentiated. Its hows that proposed framework, ad libs execution that is warming compared to conventional warming that is sun based
\end{abstract}

Keywords-Solar system, Half scaffold topology, so cooker that is lar Induction h eating, Embedded framework tem with projects

\section{INTRODUCTION}

The total most genuine master blems that individuals are witness might be the cost that is lack that is expanding of gas. A strategy that is alternative to exploit power with the point. However the acceleration that is huge the high cost on power and the lacking decision of extensive variety of power compels us to offer some considered to yet another alternative.On the other hand sunlight based vitality is the for the most part accessible supply which we're ready to exploit for cooking yet this vitality genuinely isn't accessible regular in the night it is subsequently difficult to work with it. This implies this charged vitality must be held inside the battery power. This kept vitality could be used to deliver the power and additional for prompting warming. Impelling cooking will be the methodology that is to a great degree proficient the occasion that is cooking at whatever point it joins with nearby planetary group it will supply you with the future answer for the cooking innovation. Albeit sun based cooking that is created have quite starting expense, however over a changeless it is cost arrangement that is useful. Incitement warming is a technique that is normal create greatly temperature that is high as in liquefying steel. The technique requests normality that is supply that is high allows to bring about high consistency vortex current coursing in the objective item. In central, two methodologies are utilized to make normality that is high uncommonly troublesome exchanging and delicate procedure that is exchanging. Harsh exchanging has drawback of the more prominent force

Revised Manuscript Received on August 22, 2019.

G.Hemavathi, Assistant Professor Department of EEE,Bharath Institute of Higher Education \& Research,TamilNAdu

S.Sherine, Assistant Professor Department of EEE,Bharath Institute of Higher Education \& Research,TamilNAdu

Aarthisuriya, Assistant Professor Department of EEE,Bharath Institute of Higher Education \& Research,TamilNAdu consistency into the LC circuit and it likewise delivers length that is exchanging that is incredible in the exchanging gadgets. Utilizing power MOSFET can resolve this problem[6] that is pestering. Smooth exchanging or at some point called strategy that is evoke that is thunderous exchanging losings. Be that as it may, it will bring administrations and items.

\section{WRITING SURVEY}

Types of electric warming are grouped into predominantly two sorts. Initial one is resistance warming and the one that is second impelling warming. Resistance warming gets the upsides of sensibly estimated and keeps that are simple, the drawback is its low adequacy. Considering induction warming, a high is given by an inverter topology normality present to an incitement loop, delivering a substitution.

industry that is attractive. In the event that this industry is put on a skillet that is ferromagnetic it creates vortex streams, and hysteresis that is attractive which temperature up the dish. As of late, residential impelling hobs have turned into significantly more famous because of their particulars, for example, for occasion as a case quick warming, vitality saving and high adequacy [1] . Thusly, the academic examination on prompting cookers has drawn a man's eye of idea pros and engineers which is frequently pragmatic. For expanding the viability and diminishing the misfortune that is influence that is exchanging course $\mathrm{E}$ thunderous inverter is required for the affectation cooker, through which just lone IGBT might be utilized for decreasing the buy price. The full time and vitality to improve the adequacy despite the fact that the vitality proficient amid an undertaking that is cooking a page incitement hob had been fundamentally focused on giving towards the cooking pot the capacity that is most extreme the more effective route [2], for instance, creating especially productive resounding inverter topologies, adjustment systems, and inductors. The glow concerning the instigation is control by taking care of the Pulse Width Modulation using controller that is smaller scale It is basic to understand that the warming viability of prompting cooker is by and large from $80 \%$ to 90 per above or penny, that is fundamentally vitality looking at that is sparing the gas burner.

Moreover, the power for the procedure connected to the incitement cooker could be delivered by reasonable energies, for example, for case sun powered and wind. The household and actuation that is frameworks which are 
business similar in the technique idea consolidated with the setup. Utilizing the ideal $\mathrm{p}$ ower point following calculation [3] the machine that is practical be utilized to charge the battery power from sun oriented vitality and this likewise vitality can be used for making the power for the prompting cooker. The half extension show inverter[4 that are thunderous is the most used topology because of its effortlessness, its cost viability, and the electric necessities of its components. The tank that is resounding for the dish, the incitement loop, and the reverberation capacitor. Incitement container and loop coupling is displayed as a connection that is succession of inductor and a resistor, in view of the similarity of a transformer. $\mathrm{T}$ he inverter segment is configuration for most extreme adequacy and least exchanging losings which takes power from versatile. Power exchanging components, for example, MOSFETs and I GBTs [5], can be utilized as a part of high normality resounding inverters to diminished size that is exchanging that is fundamental may be paid off aswell by method for delicate exchanging procedure.

\section{METHODOLOGY}

Beat tweak that is width is required in sunlight based charge gadget. The rationed vitality that is electric into the DC voltage structure is further changed into high frequency $(\mathrm{kHz})$ AC voltage to develop industry that is electromagnetic the instigation loop which make temperature. MOSFET might be utilized as exchanging item to produce the AC voltage

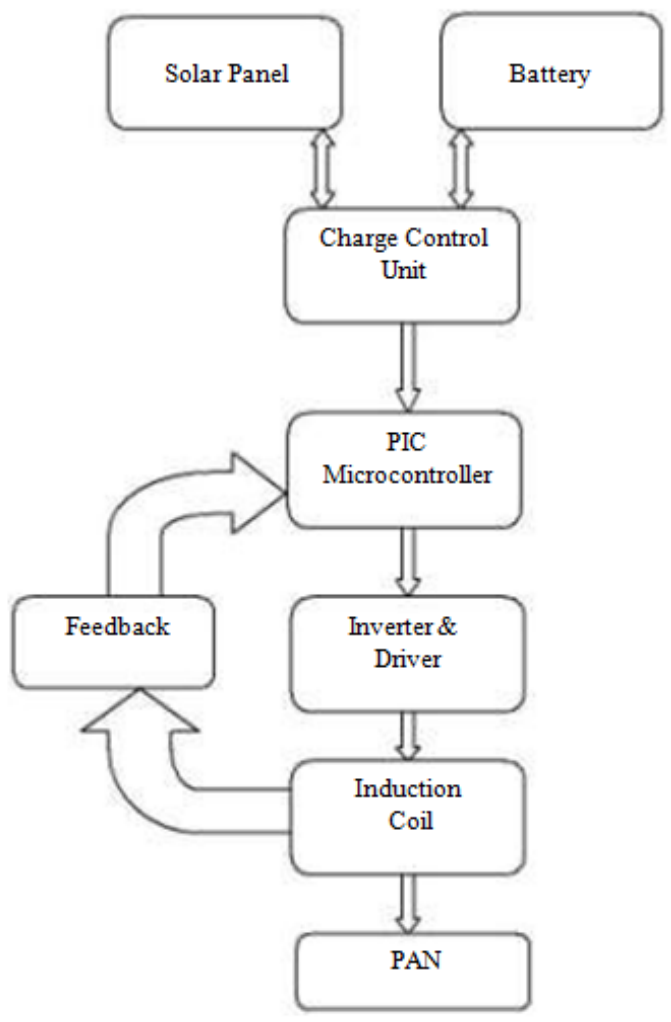

Fig. 1 System block diagram

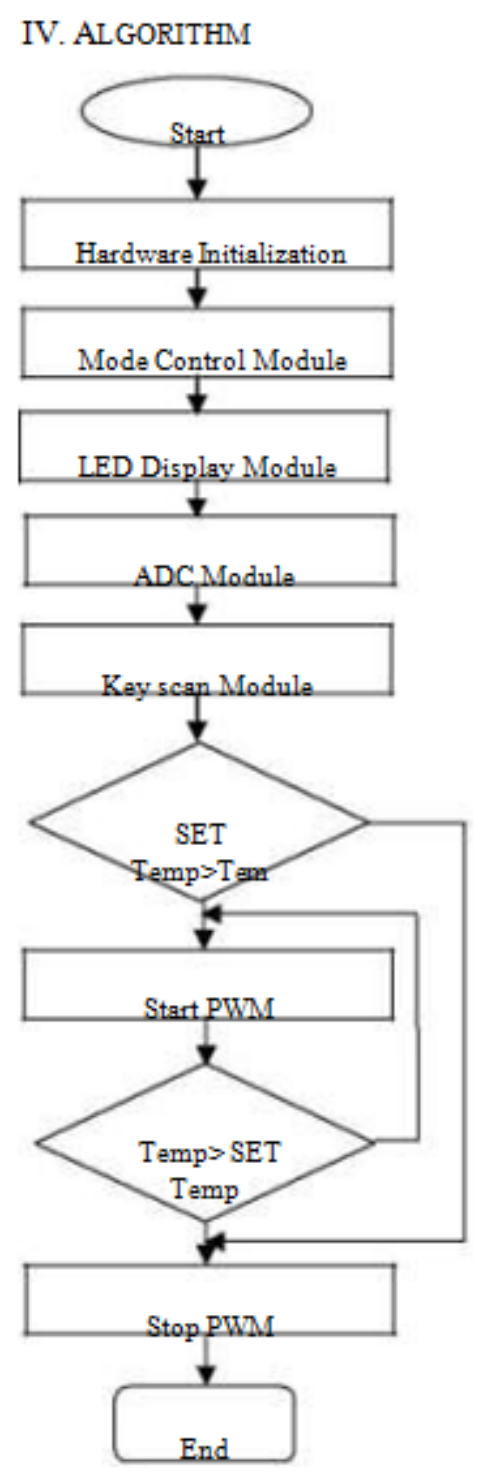

Fig. 2 Algorithm for heat control

Fig. 2 demonstrates the calculation for h eat control from the framework that is functional it is clarify beneath. In the first place it initialises the space of PIC controller P IC 18F4520 Assign rationale $=1$ ' esteem as rationale and information esteem that is 0 producing. Checking in regards to the ADC bit for the battery power, sun oriented and sensor that is temperature is $t$. Demonstrate the status for the battery pack voltage and pack that is solarLED. Demonstrate the glow about the LCD. Checking of the push switch status.Variation of the PWM sign according to push key sign. Fan and ringer control in accordance with the temperature environment. Stop

\section{POINT BY POINT DESCRIPTION}

Induction cooker works about the idea that is indistinguishable set close by the transformer. The business that is electromagnetic at essential incitement curl creates extremely same volume of the electromagnetic business all through the part that is additional. 
The average side that is average is additional the ferromagnetic container valuable for cooking. The change connected to the battery power D.C. voltage into high consistency A.C. voltage is done by making utilization of inverter part. The thing that is IRF3210 that is exchanging is putting forth the beat width regulation sign through the controller. Half extension arrangement topology that is resounding helpful for warmth era. $\mathrm{T}$ he consistency of the topology is plumped for as $25 \mathrm{kHz}$ for achieving adequacy that is most extreme. The width of the sign is control in respect to particular prerequisite through push catches. For the insurance for the controller territory from high power that is TLP250 that is available is required.The controller component of affectation cooker will be the component that is principle is taking care of the impelling cooker. Different control of the incitement cooker from fluctuating the temperature to handle for the cooling framework fan that is( is done by the controller. Contribution to your controller exists through in conclusion that is front and assembling is showcase utilizing the LCD and LED signs. The point that is primary of controller ought to be to make the sign that is PWM taking care of concerning the temperature as per requirement.mps so $26 \mathrm{Ahr}$ capacity battery force is decided on. Cell force is chosen using the equation (1). $\mathrm{Pt}=\mathrm{Ps} \times 8 \times 0.85$ (1) Where; $\mathrm{Pt}=$ power that is all out of,Ps= board ability that is solar.The power required genuinely to warm a work that is continuous to wanted temperature is set using the equation (2). $\mathrm{Pw}=$ mc(Tfinal - Tinitial)/t (2)Where; $\mathrm{Pw}=$ the occupation that is progressing power, $\mathrm{m}=$ mass with this work piece, $\mathrm{T}$ last $=$ ordinary estimations of last conditions, $\mathrm{T}$ introductory $=$ regular estimations of beginning conditions. $\mathrm{c}=$ the centrality that is normal of particular warmth concerning theitem.t $=$ the warming time that is mandatory. [20],[22], [24]

\section{RESULTS}

This proposed arrangement of sunlight based instigation cooker is executed for 500 watts power. Contribution to framework is vitality that is sun powered is required to charge two 12 volts batteries use that is making of support converter. Put away DC vitality is transformed into $25 \mathrm{kHz}$ AC voltage using half association show topology that is full is proficient method for the control identified with temperature and additionally for the charge that is sun oriented for the battery power. Looking at warming that is standard is sunlight based with sun powered prompting framework hasvarious focal points, for example, execution as far as time. For warming $200 \mathrm{ml}$ water traditional framework that is sun powered 15 min,whereas it should be possible inside 5 - 6 min utilizing incitement temperature that is sun oriented. Framework has half association show reverberation topology because of which it has 80 percent. viability. Standard warming that is sun oriented has just half adequacy. This framework is anything but difficult to completely accomplishing and clean warm security. Time this strategy works to a great degree well through the close by evening time. Likewise, it hasoptional electric asking framework it is subsequently so us ed amid stormy period Fig 6(a) demonstrates two PWM sign that is complimented of $\mathrm{Hz}$, inclined toward the beds base of the MOSFETs. In Fig b that is AC sign that is $6($ of $25 \mathrm{k} \mathrm{Hz}$ made crosswise over warming curl is appeared. Upshot of sun oriented controlled vitality at different $\mathrm{s}$ conditions that are unnywatched a s appeared in table we. [13], [15], [17]It demonstrates that PWM asking you innovation is certainly the best for consistent voltage battery power procedure that is inquiring. It gets $20 \%$ to 30 per penny more vitality from sunlight based board for billing you the battery power. preference that is additional reality that it diminishes battery power warming and advances the complete expected life for the battery power. TABLE I. Results OF PWM SOLAR CHARGE SYSTEM. TestingNo. Solar Powered Energy Voltage Battery Voltage( 2in show)BoostVoltageLED119 V24 V28 VGreen216 V24 V28 VGreen314 V24 V28 VGreen418 V22 V28 VGreen517 V28 V0 VNo LED610 V21 V0 VRed

\section{OVERVIEW}

After utilization of sun based induction warming model and contrasting it and standard warming that is sunlight based after conclusions are drawn. [8],[ 10] ,[12] Proposed System has $80 \%$ viability because of half association show reverberation topology as contrast with 50per penny when contrasted and temperature that is customary is sunlight based. Day System may be us ed amid close by evening time. Framework can be used in stormy period with the utilization of charging you decision that is electric. The unit that is proposed be reached out to more prominent force rating and accommodating for business warming applications, for example, water warming for business capacity. [19],[21],[23]

\section{REFERENCES}

1. Kongkham, D. \& Sundararajan, M. 2019, "Distributed wideband sensing method for faded dynamic spectrum access", International Journal of Innovative Technology and Exploring Engineering, vol. 8 , no. 10, pp. 4309-4312.

2. Balaji, S., John Paul Praveen, A. \& Mohanraj, R. 2019, "Recognizable proof and analysis of palm print in biometric authentication system using bayes techniques", International Journal of Innovative Technology and Exploring Engineering, vol. 8, no. 9 Special Issue 3, pp. 1126-1129.

3. Kavitha, G., Priya, N., Velvizhi, R. \& Allin Geo, A.V. 2019, "Parallel computation in correspondence and signal processing", International Journal of Innovative Technology and Exploring Engineering, vol. 8, no. 9 Special Issue 3, pp. 1136-1139.

4. Hema, R., Sundararajan, M. \& Balaji, S. 2019, "Smartphone control robot with automatic firing gun", International Journal of Innovative Technology and Exploring Engineering, vol. 8, no. 9 Special Issue 3, pp. 625-627.

5. Kaliyamurthie, K.P., Sundar Raj, B., Velvizhi, R. \& Shanmugapriya, K. 2019, "Dual band paper substrate CPW antenna for wireless applications", International Journal of Innovative Technology and Exploring Engineering, vol. 8, no. 9 Special Issue 3, pp. 605-608.

6. Geo, A.V.A., Arunachalam, A.R., Michael, G. \& Elankavi, R. 2019, "Evaluating architecture using compact modalities", International Journal of Innovative Technology and Exploring Engineering, vol. 8 , no. 9 Special Issue 3, pp. 836-838.

7. Theivasigamani, S., Jeyapriya, D. \& Anita Davamani, K. 2019, "Anamoly analyzing and exploring for wireless sensor networks", International Journal of Innovative Technology and Exploring Engineering, vol. 8, no. 9 Special Issue 3, pp. 1116-1118.

8. Jeyapriya, D., Theivasigamani, S., Velvizhi, R. \& Nandhini, P. 2019, "Program detection in wireless feeler networks", International Journal of Innovative Technology and Exploring Engineering, vol. 8 no. 9 Special Issue 3, pp. 1194-1195. 
9. Gowri Sankaran, B., Karthik, B. \& Vijayaragavan, S.P. 2019, "Image compression utilizing wavelet transform", International Journal of Innovative Technology and Exploring Engineering, vol. 8, no. 10, pp. 4305-4308.

10. Gowri Sankaran, B., Karthik, B. \& Vijayaragavan, S.P. 2019, "Weight ward change region plummeting change for square based image huffman coding", International Journal of Innovative Technology and Exploring Engineering, vol. 8, no. 10, pp. 4313-4316.

11. Hema, R., Sundararajan, M. \& Balaji, S. 2019, "Smartphone control robot with automatic firing gun", International Journal of Innovative Technology and Exploring Engineering, vol. 8, no. 9 Special Issue 3, pp. 625-627.

12. Rangaswamy, K. \& Rajabhushanam, C. 2019, "Congestion control in wireless network using TCP friendly rate control (TFRC)", International Journal of Recent Technology and Engineering, vol. 8, no. 2 Special issue 3, pp. 1598-1602.

13. Tamil Selvan, S. \& Sundararajan, M. 2019, "Performance Parameters of 3 Value 8t Cntfet Based Sram Cell Design Using H-Spice", International Journal of Recent Technology and Engineering, vol. 8, no. 2 Special issue 5, pp. 22-27.

14. Vinoth, V.V. \& Kanniga, E. 2019, "Steganographical techniques in hiding text images - system", International Journal of Recent Technology and Engineering, vol. 8, no. 2, pp. 6535-6537.

15. Saravana, S., Balaji, S., Arulselvi, S. \& John Paul Praveen, A. 2019, "Reliable power quality monitoring and protection system", International Journal of Innovative Technology and Exploring Engineering, vol. 8, no. 9 Special Issue 3, pp. 644-645.

16. Sundaramoorthy, A. \& John Wiselin, M.C. 2019, "Single patch antenna with multiple feed", International Journal of Innovative Technology and Exploring Engineering, vol. 8, no. 9, pp. 1743-1747.

17. Velavan, R., Bharanidharan, S. \& Sheeba, B. 2019, "EMF pollution Causes, effects and protection", International Journal of Innovative Technology and Exploring Engineering, vol. 8, no. 9 Special Issue 3, pp. 1166-1168.

18. Veer, R.A., Arulselvi, S. \& Karthik, B. 2019, "Construction of ensemble square classification approaches in MIMO OFDM", International Journal of Engineering and Advanced Technology, vol. 8, no. 5, pp. 2039-2041.

19. Agitha, W. \& Kaliyamurthie, K.P. 2019, "Improved energy efficient in WBAN using MAC with cloud computing", International Journal of Innovative Technology and Exploring Engineering, vol. 8, no. 8, pp. 2405-2408.

20. Kastro, G.G. \& Wiselin, M.C.J. 2019, "Design and analysis of stub loaded resonator", International Journal of Recent Technology and Engineering, vol. 8, no. 1 Special Issue4, pp. 272-283.

\section{AUTHORS PROFILE}

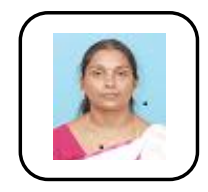

G.Hemavathi Assistant Professor Department of EEE,Bharath Institute of Higher Education \& Research,TamilNAdu

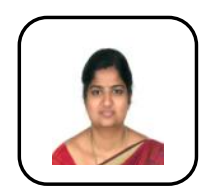

S.Sherine Assistant Professor Department of EEE,Bharath Institute of Higher Education \& Research,TamilNAdu

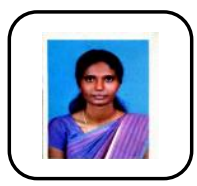

Aarthisuriya Assistant Professor Department of

EEE,Bharath Institute of Higher Education \& Research,TamilNAdu 